\title{
Validation of a real-time PCR assay for the molecular identification of Mycobacterium tuberculosis
}

\author{
Mariana L. Sales ${ }^{1}$, Antônio Augusto Fonseca Júnior ${ }^{1}$, Lívia Orzil ${ }^{1}$, \\ Andrea Padilha Alencar ${ }^{1}$, Marcio Roberto Silva ${ }^{2}$, Marina Azevedo Issa ${ }^{1}$, \\ Paulo Martins Soares Filho ${ }^{1}$, Andrey Pereira Lage ${ }^{3}$, Marcos Bryan Heinemann ${ }^{3}$ \\ ${ }^{1}$ Laboratório Nacional Agropecuário de Minas Gerais, Pedro Leopoldo, MG, Brazil. \\ ${ }^{2}$ EMBRAPA Gado de Leite, Juiz de Fora, MG, Brazil. \\ ${ }^{3}$ Escola de Veterinária, Universidade Federal de Minas Gerais, Belo Horizonte, MG, Brazil.
}

Submitted: March 27, 2013; Approved: April 17, 2014.

\begin{abstract}
Mycobacterium tuberculosis is the major cause of tuberculosis in humans. This bacillus gained prominence with the occurrence of HIV, presenting itself as an important opportunistic infection associated with acquired immunodeficiency syndrome (AIDS). The current study aimed to develop a real-time PCR using Eva Green technology for molecular identification of M. tuberculosis isolates. The primers were designed to Rv1510 gene. Ninety nine samples of M. tuberculosis and sixty samples of $M$. bovis were tested and no sample of the bovine bacillus was detected by the qPCR. Statistical tests showed no difference between the qPCR and biochemical tests used to identify the Mycobacterium tuberculosis. The correlation between tests was perfect with Kappa index of 1.0 $(\mathrm{p}<0.001, \mathrm{CI}=0.84-1.0)$. The diagnostic sensitivity and specificity were $100 \%$ (CI $=95.94 \%$ $100 \%)$ and $100 \%(\mathrm{CI}=93.98 \%-100 \%)$. This qPCR was developed with the goal of diagnosing the bacillus $M$. tuberculosis in samples of bacterial suspension. TB reference laboratories (health and agriculture sectors), public health programs and epidemiological studies probably may benefit from such method.
\end{abstract}

Key words: Mycobacterium tuberculosis, diagnosis, real time PCR.

\section{Introduction}

Tuberculosis (TB) is one of the oldest and most serious known diseases. Studies using DNA isolated from cattle bones found in North America, which were dated to 17,000 BC, showed the presence of Mycobacterium tuberculosis (Rothschild et al., 2001). During the Industrial Revolution, numerous cases of tuberculosis emerged due to the agglomeration of workers (Costa, 1985). In the first half of the twentieth century, the disease terrorized Europe, and a diagnosis meant a death sentence for $50 \%$ of infected individuals, mostly children and youth (Daniel et al., 1984).

There was hope that tuberculosis would be eradicated by 2000 in developed countries, However, with the AIDS pandemic, pulmonary tuberculosis has become the third most common opportunistic infection in HIV-positive patients (Job, 1998). The occurrence of TB co-infection with human immunodeficiency virus (HIV) caused a change in the epidemiological trends of TB, which now presented as an important opportunistic pathogen associated with acquired immunodeficiency syndrome (AIDS) (Carvalho, 2006). According to estimates from the World Health Organization (WHO), one third of the world population is infected with Mycobacterium tuberculosis; every year, 8 million people become ill and 2,9 million people die as a result of TB infection (WHO, 2013). Of the 8 million cases registered annually, 95\% occur in developing countries (Brasil, 2002). In the past, pulmonary tuberculosis was used as an indicator of peripheral development.

While mycobacterium culture is the gold standard for confirmation of a TB diagnosis, the process requires more than three weeks for a conclusive result and is not species-level specific. The major problems in mycobacteria 
identification by phenotypic methods are the variety of biochemical tests required and the time needed for completion of the tests (Telenti et al., 1993). These tests can be laborious, time consuming, inaccurate and non-reproducible, can generate ambiguous results and require adequate facilities with a high biosecurity level (Huard et al., 2003).

Molecular biology techniques are widely applicable to laboratory diagnoses of infectious diseases caused by viruses (Fonseca Jr. et al., 2010), bacteria (Cortez et al., 2006), parasites or fungi (Sotiriadou et al., 2013). DNA fragment amplification opened excellent prospects for the detection of infectious agents. PCR has several advantages compared to traditional diagnosis methods. PCR is highly sensitive, specific and rapid. To produce a positive diagnosis, fewer bacterial cells are required, and the bacteria do not need to be viable, which means that inadequately preserved samples can be used (Abrahão, 1999, Narayanan, 2004). Real-time PCR (qPCR) has further advantages, including precision, reproducibility, accuracy, quality control processes and reduced contamination. In addition, qPCR eliminates the need for electrophoresis after the cycling reaction. Furthermore, this technique reduces the analysis time to three or four days, which is important in laborious and lengthy microbiological diagnoses, such as those required for TB.

Faster diagnoses of human TB is of significant clinical importance. There are commercial methods available to detect $M$. tuberculosis, but these techniques rely on multiple probes or detect Mycobacterium tuberculosis complex (MTC) but not the specific species (Rossau et al., 1997). Thus, the aim of this study was to develop a real-time PCR assay using bacterial suspensions and Eva Green ${ }^{\circledR}$ to identify $M$. tuberculosis as an alternative to phenotypic tests.

\section{Materials and Methods}

\section{qPCR}

The oligonucleotides designed in this study were based on the complete genome sequence of M. tuberculosis (Cole et al., 1998). First, the sequences were subjected to BLAST $^{\circledR}$ (http://blast.ncbi.nlm.nih.gov/Blast.cgi) for verification of genomic differences (Altschul et al., 1997). Then, the selected target sequences available on GenBank (NCBI, http://www.ncbi.nlm.nih.gov/) were aligned in BioEdit (16). After checking the ideal regions, namely, those present only on $M$. tuberculosis, primers were designed in the Primer3Plus program (Untergasser et al., 2007) and analyzed using the Oligo Analyser 3.1 program (IDT, USA) for verification of secondary structures. In silico analytical specificity of the primers was tested with the PrimerBlast program (NCBI, http:/www.ncbi.nlm.nih.gov/tools/primer-blast/index.cgi?LINK_LOC=BlastHome) (Altschul et al., 1990).

The region chosen for the specific detection of $M$. $t u$ berculosis DNA was the gene Rv1510. Primers
Mtub.115.F: 5'TTCGATATTCGCGGTGTTTT3' (318446-318465, referring to BX842576.1) and Mtub.115.R: 5'CGCAACTATTTGGGTGGAG3' (318542-318560) amplify a 115 bp segment of the gene. The ideal qPCR reactions contained 10 pmol of each primer (IDT, USA), 1.5 U Hot Start GoTaq Polymerase (Promega, USA), 20\% Colorless GoTaq Hot Start Buffer 5x, 1.5 mM $\mathrm{MgCl}_{2}, 1 \mu \mathrm{L}$ of $20 \mathrm{x}$ Eva Green (Biotium, USA), $2 \mu \mathrm{L}$ Rox 10x (Biotium, USA), $10 \mathrm{mM}$ dNTPs and $2 \mu \mathrm{L}$ of DNA to a final volume of $20 \mu \mathrm{L}$. All tests were performed on a Rotorgene 3000 (Qiagen, Germany) with the following program: denaturation at $95{ }^{\circ} \mathrm{C}$ for 3 min followed by 35 cycles at $95{ }^{\circ} \mathrm{C}$ for $10 \mathrm{~s}, 60{ }^{\circ} \mathrm{C}$ for $15 \mathrm{~s}$ and $72{ }^{\circ} \mathrm{C}$ for $20 \mathrm{~s}$ with fluorescence readings. The melting curve was performed with the following parameters: $45 \mathrm{~s}$ at $72{ }^{\circ} \mathrm{C}$ and $3 \mathrm{~s}$ per degree up to $99^{\circ} \mathrm{C}$. DNA extraction was evaluated by qPCR targeting ribosomal DNA. Primers M.sp.rDNA.133.F (5'GTCCTTGGAGACGTTCCTCA3') and M.sp.rDNA.133.R (5'CACGTCGATCACCACG TAGA3') were used with the same reagent concentrations and cycling conditions that were used for Rv1510 detection.

\section{Samples}

Standard M. tuberculosis strains H37Rv CRNC 23 and H37Ra CRNC 25 were used as positive controls, and M. bovis AN5 Mexico CRNC 36, M. bovis AN5 CRNC 02, $M$. bovis AN5 CRNC 01 and M. bovis BCG CRNC standard strains were used as negative controls for all tests in this study.

\section{Phenotype-based speciation methods}

All positive AFB cultures were subjected to additional phenotypic speciation methods, including biochemical tests such as catalase at room temperature and at $68^{\circ} \mathrm{C}$, niacin, nitrate, pyrazinamidase, and urease. Drug susceptibility testing (DST) was used to distinguish mycobacterial strains (Job, 1998).

\section{Molecular-based speciation methods}

Two loops of each mycobacteria replica that grew on Lowenstein Jensen or Stonebrink media were transferred into a microcentrifuge tube containing $400 \mu \mathrm{L}$ of $1 \mathrm{X}$ TE buffer and were separately subjected to heat to kill and lyse the cells. The inactivated isolates were stored at 2 to $8^{\circ} \mathrm{C}$ until use in the PCR reactions.

A rapid differentiation of $99 M$. tuberculosis isolates and $60 \mathrm{M}$. bovis isolates was performed by molecular methods to confirm the real situation of the study samples. $M$. $t u$ berculosis samples were previously isolated and kindly provided by Embrapa Gado de Leite. M. bovis isolates were collected in Lanagro/MG slaughterhouses from tissues with lesions characteristic of bovine tuberculosis and tested in qPCR previously validated by our group (Sales et al., 2014a, Sales et al., 2014b). The mycobacterial DNA was 
subjected to amplification of the pncA gene (Scorpio and Zhang, 1996) and detection of the pncA polymorphism by cleavage of the amplicon with Eco065I, as previously described (Barouni et al., 2004) for the genetic identification of M. bovis or M. tuberculosis. This analysis was carried out at the Laboratory of Molecular Biology Applied to Mycobacteria, Oswaldo Cruz Institute, Fiocruz.

\section{Validation criteria}

The parameters for the validation methodology were performed according to the Manual of Diagnostic Tests and Vaccines for Terrestrial Animals (OIE, 2010).

\section{Reaction efficiency}

The reaction efficiency was tested by examining 10-fold dilutions in 1X TE buffer of DNA extracted from the positive controls. Each dilution was tested in duplicate and the concentration estimated on a Nanovue ${ }^{\circledR}$ (GE Healthcare, USA) spectrophotometer. A number of standard curves were generated to determine the optimal primer concentration.

\section{Limit of Detection (LOD) and Analytical Specificity}

The determination of the LOD was performed by the 10 -fold dilution of the standard strain. The dilutions were tested in triplicate, and the LOD was determined as the dilution at which all replicates were positive. The LOD was confirmed by repeating the qPCR twenty-one times.

The following strains were used in analytical specificity tests: $60 \mathrm{M}$. bovis isolates, $M$. fortuitum CRNC 10, $M$. kansasii CRNC 48 and CRNC 18, M. gordonae CRNC 16, M. avium D4 CRNC 05, M. avium paratuberculosis CRNC 26, M. avium $1500 \mathrm{CRNC} 15$ and 2045 CRNC 14, $M$. intracellulare CRNC 17, M. marinum CRNC 19, M. scrofulaceum CRNC 49, M. scrofulaceum CRNC 20, $M$. szulgai CRNC 21, M. triviale CRNC 22, M. fortuitum peregrinum CRNC 11, M. phei CRNC 12, Rhodococcus equi CRC 09/01, Corynebacterium pseudotuberculosis CRC 09/02 and Nocardia asteroides CRC 10/01.

\section{Repeatability}

The repeatability was estimated using seven samples of $M$. tuberculosis and three samples of M. bovis. We extracted DNA from seven samples on three different days and subjected the extracted nucleic acid to qPCR. To assess possible changes in the test, a second analyst performed the technique using the same criteria and the same samples.

\section{Robustness}

We analyzed the assay robustness with potential issues that may occur, such as an improperly calibrated pipette or thermocycler, to evaluate how these problems would impact the diagnosis of human tuberculosis. Five $M$. tuberculosis samples and five $M$. bovis samples were used in a qPCR assay with a $1{ }^{\circ} \mathrm{C}$ increased annealing tempera- ture and $10 \%$ less enzyme, $\mathrm{MgCl}_{2}$ and primers. A second qPCR was performed with a $1{ }^{\circ} \mathrm{C}$ decreased annealing temperature and $10 \%$ more enzyme, $\mathrm{MgCl}_{2}$ and primers.

\section{Statistical analysis}

We used the McNemar test to compare paired proportions, the kappa test to determine the measure of agreement between two tests for each sample and the sensitivity and specificity analysis (Kraemer, 1992).

For the diagnostic sensitivity and diagnostic specificity analyses, 99 M. tuberculosis isolates from Brazil were used. Each sample was simultaneously tested by phenotypic and qPCR methods. The qPCR method was compared with the phenotype-based speciation method as a gold standard.

\section{Results}

qPCR

The average melting temperature for positive samples in the qPCR for M. tuberculosis was $94.11^{\circ} \mathrm{C}$ with a standard deviation of $1.31^{\circ} \mathrm{C}$. The qPCR was able to detect up to $9.88 \times 103$ copies/ $\mu \mathrm{L}$ in a standard curve with an $\mathrm{R}^{2}$ of $99 \%$ and with $78 \%$ efficiency (Table 1 ). The average melting temperature for positive samples in the qPCR for ribosomal DNA was $87.2^{\circ} \mathrm{C}$.

\section{Repeatability and robustness}

The qPCR had similar results when performed on different days and by a different analyst. The average melting temperature was $94.72{ }^{\circ} \mathrm{C}$ with a standard deviation of $0.26^{\circ} \mathrm{C}$. No amplification was detected when $M$. bovis DNA was used. Variations in cycle thresholds $(\mathrm{Ct})$ and melting temperatures detected in the robustness tests are described in table 2 and Figure 1.

\section{Statistical analyses}

The McNemar test showed no significant difference between the qPCR $(p=0.3173)$ and microbiological isolation methods, and the Kappa test showed perfect agreement $(0.98)$ between the two tests.

\section{Sensitivity and specificity}

The qPCR detected only DNA extracted from $M$. $t u$ berculosis. All other nucleic acid from other Mycobacte-

Table 1 - Mean values $\sigma$ of $\mathrm{Ct}$ and standard deviations of qPCR.

\begin{tabular}{lccc}
\hline Copies $/ \mu \mathrm{L}$ & Concentration $(\mathrm{ng} / \mu \mathrm{L})$ & $\mathrm{Ct}$ & $\sigma$ \\
\hline $9.88 \times 10^{6}$ & 47.5 & 20.56 & 0.64 \\
$9.88 \times 10^{5}$ & 4.7 & 24.03 & 0.24 \\
$9.88 \times 10^{4}$ & 0.47 & 28.95 & 0.48 \\
$9.88 \times 10^{3}$ & 0.047 & 32.64 & 0.41 \\
$9.88 \times 10^{2}$ & 0.0047 & - & - \\
\hline
\end{tabular}


Table 2 - Variation of melting temperature and cycle threshold in robustness tests for qPCR.

\begin{tabular}{|c|c|c|c|c|c|}
\hline \multirow[t]{2}{*}{ Species } & \multirow[t]{2}{*}{ Sample } & \multicolumn{2}{|c|}{ Robustness $1 *$} & \multicolumn{2}{|c|}{ Robustness 2} \\
\hline & & $\mathrm{Ct}$ & Melting & $\mathrm{Ct}$ & Melting \\
\hline \multirow[t]{5}{*}{ M. tuberculosis } & 1 & 12.95 & 94.4 & 19.44 & 94.1 \\
\hline & 2 & 18.31 & 94.4 & 29.44 & 94.5 \\
\hline & 3 & 16.30 & 94.5 & 26.73 & 94.4 \\
\hline & 4 & 17.37 & 93.56 & 24.88 & 93.63 \\
\hline & 5 & 19.36 & 94.43 & 31.76 & 93.6 \\
\hline \multirow[t]{5}{*}{ M. bovis } & 1 & - & - & - & - \\
\hline & 2 & - & - & - & - \\
\hline & 3 & - & - & - & - \\
\hline & 4 & - & - & - & - \\
\hline & 5 & - & - & - & 一 \\
\hline
\end{tabular}

*Robustness 1 : increase in $1{ }^{\circ} \mathrm{C}$ in annealing temperature and $10 \%$ less enzyme, $\mathrm{MgCl}_{2}$ and primers; Robustness 2 : decrease by $1{ }^{\circ} \mathrm{C}$ temperature annealing and $10 \%$ more enzyme, $\mathrm{MgCl}_{2}$ and primers.
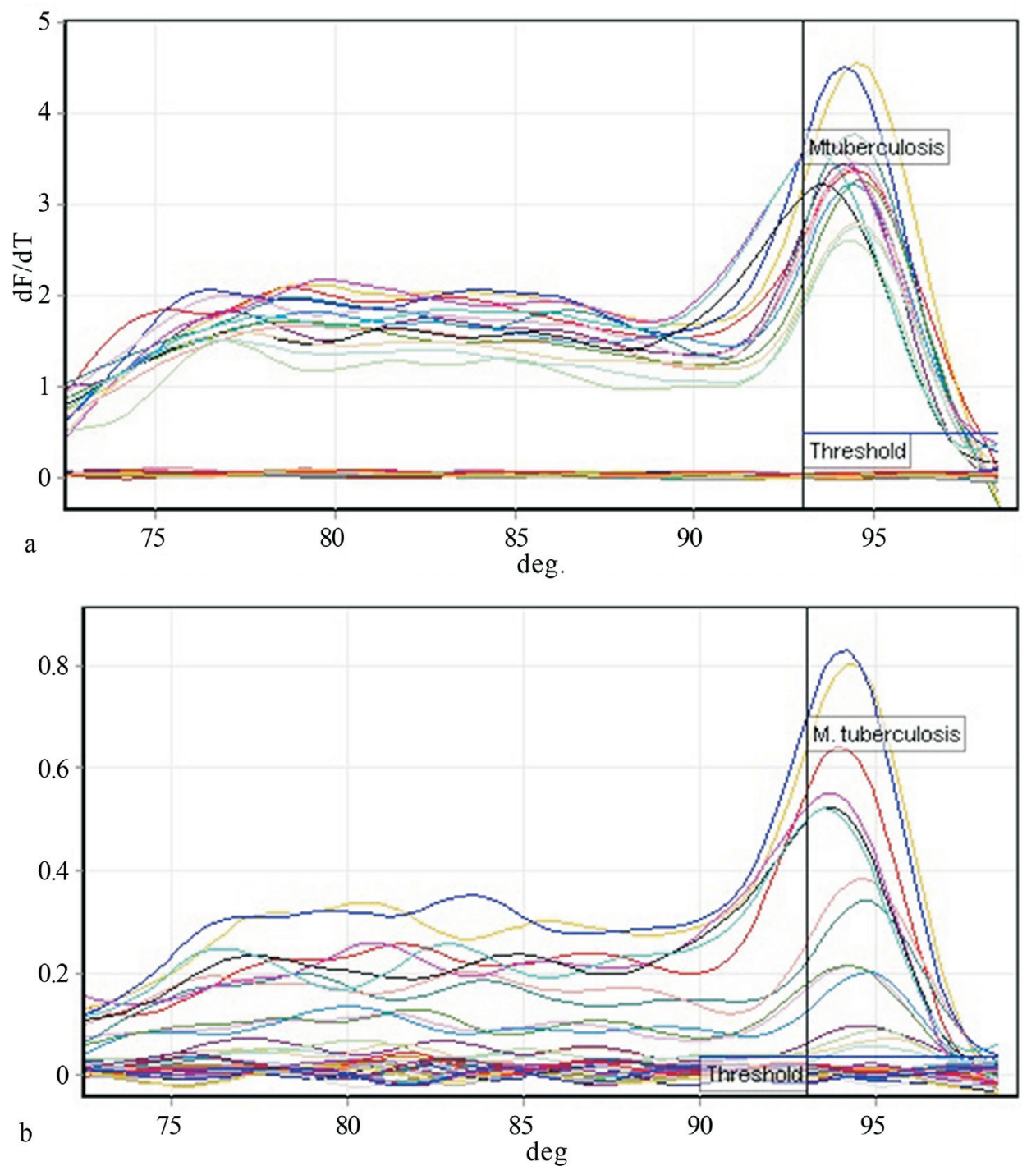

Figure 1 - Denaturation curve (dF/dT vs. temperature) of positive and negative samples used in robustness 1 (a) and robustness 2 (b) for qPCR-Mtub-115. 
rium and another bacterial species tested in this work were negative in all of the performed tests. The diagnostic sensitivity and specificity were $100 \%(\mathrm{CI}=95.94 \%-100 \%)$ and $100 \%$ (CI $=93.98 \%-100 \%)$, respectively.

\section{Discussion}

Phenotypic tests used to identify Mycobacterium isolates are time consuming and unreliable. The use of molecular tests to correctly identify microorganisms is fast, reliable and sensitive. The qPCR developed in this study did not amplify DNA from any of the Mycobacterium spp. other than the M. tuberculosis samples used in the analytical specificity tests; positive results were only realized for the M. tuberculosis strains used as positive controls.

The qPCR tests described here do not detect three species of the MTC: $M$. canettii, $M$. africanum 1 and $M$. africanum 2. However, these results do not invalidate the use of this qPCR assay outside of Africa. M. africanum and $M$. canettii cause human tuberculosis but are restricted to Africa or cases closely related to that continent. Medical treatment for infections caused by these species is the same as for M. tuberculosis (Frothingham et al., 1999, van Soolingen et al., 1997). There are a few cases related to $M$. africanum in countries closely related to West Africa. Spain, for example, has more than 7500 cases of tuberculosis per year but registered only 57 cases caused by $M$. africanum between 2000 and 2010 (Isea-Peña et al., 2012). We focused on the differentiation of M. tuberculosis and $M$. bovis. TB due to Mycobacterium bovis, the causative agent of bovine tuberculosis, is clinically indistinguishable from human TB due to M. tuberculosis and is an important cause of infection in developing countries (Silva et al., 2013). This discrimination is possible only by the use of specific culture media and subsequent characterization by phenotypic and molecular speciation methods. The treatment for $M$. bovis infection differs from $M$. tuberculosis infection due to the natural resistance to pyrazinamide (Ruggiero et al., 2007).

The efficiency of the qPCR was $78 \%$, indicating the presence of inhibitors in the reaction, likely primer dimers or the formation of secondary structures in the amplicon. In fact, the primers have several repetitions of nucleotides, which increase the possibility of nonspecific reactions. The amplified region is rich in guanine and cytosine $(\mathrm{G}+\mathrm{C}=$ $64 \%$ ), which may hinder both the dissociation of amplicons and the formation of new amplicons due to the secondary structures (Raso et al., 2011). Thus, this qPCR is not recommended for quantification of samples; however, the number of samples used in this work show that it is a reliable method to correctly identify M. tuberculosis.

Repeatability and reproducibility tests are required to establish a routine technique in the laboratory as stated in ISO 17025 and Principles and methods of validation of diagnostic assays for infectious diseases (OIE, 2010). This step is critical in the validation process and demonstrates that the method can be easily duplicated by another analyst and does not suffer interference from continuous repetition. The robustness tests showed that the diagnosis may be influenced by several factors together, such as a reduction in reagent amount and an increase in annealing temperature. The increase in reagent amount and the decrease in annealing temperature improved the performance of the qPCR. These changes did not amplify $M$. bovis used in the robustness tests, but it could reduce specificity, so we chose not to use it in our diagnostics.

This qPCR was developed with the goal of diagnosing the bacillus M. tuberculosis in bacterial suspension samples. Although not recommended for quantification, validation with a high number of positive and negative samples shows that it provides repeatability, reproducibility and diagnostic accuracy. It is important to validate the PCR with many samples. There are reports in literature that show unspecific results for detection of $M$. tuberculosis even when using regions considered safe for genetic characterization in MTC like RD9 and RD12 (Ueyama et al., 2014). The method validated in this work could be used as an alternative to phenotypic tests in TB diagnosis, as it is a fast, reliable technique that uses a less expensive chemistry in real time PCR. It should also be taken into account that M. tuberculosis is the most prevalent agent in human TB. In addition to the fact that a large number of samples and tests (repeatability, reproducibility and robustness) have been used to validate these techniques, the qPCR developed in this work offers advantages over other PCR tests, which rely only on single nucleotide polymorphisms (Goh et al., 2006), require electrophoresis in agarose gels (Shah et al., 2002) or were tested on only few samples (Bakshi et al., 2005). Teo et al. (2013) and Lee et al. (2010) demonstrated the importance of a PCR to correct identify M. bovis BCG infection, but used a low number of samples and a multiplex PCR based on electrophoresis in agarose gels. Reddington et al. (2011) used a multiplex real time PCR based on hydrolysis probe, buts as this kind of PCR is more expensive, it is of limited use in developing countries where tuberculosis is more prevalent. The qPCR validated in this work has advantages over these cited PCR tests, as it does not require agarose gel electrophoresis to visualize the results, it uses one of the least expensive qPCR fluorophores, and it is able to correctly identify $M$. tuberculosis in less than three hours after bacterial isolation. The results indicate that the qPCR reported here can be used in clinical laboratories that are implementing a quality system aimed at improving their ability to consistently produce valid results.

Bacterial suspensions suspected of containing M. tuberculosis could be subjected to this qPCR. If no amplification occurs, then the suspension may contain mycobacteria other than M. tuberculosis. In these cases, the same bacterial suspensions could be subjected to other phenotypic or molecular speciation methods to identify the correct spe- 
cies. Finally, TB reference laboratories (health and agriculture sectors), public health programs and epidemiological studies will likely benefit from this method.

\section{Acknowledgments}

We would like to thank $\mathrm{CNPq}$, Lanagro/MG and INCT-Pecuária. APL and MBH thank the CNPq for the fellowships.

\section{References}

Abrahão RMCM (1999) Tuberculose humana causada pelo $M y$ cobacterium bovis: considerações gerais e a importância dos reservatórios animais. Arch Vet Sci 4:5-15.

Altschul SF, Gish W, Miller W, Myers EW, Lipman DJ (1990) Basic local alignment search tool. J Mol Biol 21:403-410.

Altschul SF, Madden TL, Schäffer AA, Zhang J, Zhang Z, Miller W, Lipman DJ (1997) Gapped BLAST and PSI-BLAST: a new generation of protein database search programs. $\mathrm{Nu}-$ cleic Acids Res 25:3389-3402.

Barouni AS, Augusto CJ, Lopes MT, Zanini MS, Salas CE (2004) A pncA polymorphism to differentiate between Mycobacterium bovis and Mycobacterium tuberculosis. Mol Cell Probes 18:167-170.

Brasil (1999) Fundação Nacional de Saúde. Vigilância epidemiológica de doenças e agravos específicos: tuberculose. Ministério da Saúde. Rio de Janeiro.

Brasil - Ministério da Saúde (2002) Manual Técnico para o Controle da Tuberculose: Cadernos de Atenção Básica. Ministério da Saúde, Brasília, 16 pp.

Campos R, Pianta C (2001) Tuberculose: histórico, epidemiologia e imunologia, de 1990 a 1999, e co-infecção TB/HIV, de 1998 a 1999, Rio Grande do Sul - Brasil. Bol Saúde 15:6171.

Carvalho LGM (2006) Co-infecção por Mycobacterium tuberculosis e vírus da imunodeficiência humana: uma análise epidemiológica em Taubaté - SP. J Bras Pneumol 32:424429.

Cole ST, Brosch R, Parkhill J, Garnier T, Churcher C, Harris D, Gordon SV, Eiglmeier K, Gas S, Barry CE, Tekaia F, Badcock K, Basham D, Brown D, Chillingworth T, Connor R, Davies R, Devlin K, Feltwell T, Gentles S, Hamlin N, Holroyd S, Hornsby T, Jagels K, Krogh A, Mclean J, Moule S, Murphy L, Oliver K, Osborne J, Quail MA, Rajandream MA, Rogers J, Rutter S, Seeger K, Skelton J, Squares R, Squares S, Sulston JE, Taylor K, Whitehead S, Barrell BG (1998) Deciphering the biology of Mycobacterium tuberculosis from the complete genome sequence. Nature 393:537544.

Costa DC (1985) Considerações sobre a tendência da tuberculose no Brasil. Cad Saúde Pública 1:313-326.

Cortez A, Castro AMMG, Heinemann MB, Soares RM, Leite RC, Scarcelli E, Genovez ME, Alfieri AA, Richtzenhain LJ (2006) Detecção de ácidos nucléicos de Brucella spp., Leptospira spp., herpesvirus bovino e vírus da diarréia viral bovina, em fetos bovinos abortados e em animais mortos no perinatal. Arq Bras Med Vet Zootec 58:1226-1228.

Daniel TM, Bates JH, Downes KA (1994) History of tuberculosis. In: Tuberculosis: Pathogenesis, Prevention and Control. B.R. Bloom (ed) Am Soc Microbiol, Washington, DC.
Drosten C, Panning M, Kramme S (2003) Detection of Mycobacterium tuberculosis by real-time PCR using panmycobacterial primers and a pair of fluorescence resonance energy transfer probes specific for the M. tuberculosis complex. Clin Chem 49:1659-1661.

Fonseca Jr AA, Carmagos MF, D'Ambros RMF, Braga AC, Ciacci-Zanella J, Heinemann MB, Leite RC, Reis JKP (2010) Diagnóstico e genotipagem do vírus da pseudoraiva por nested-PCR e análise de restrição enzimática. Ciência Rural 40:921-927.

Frothingham R, Strickland PL, Bretzel G, Ramaswamy S, Musser JM, Williams DL (1999) Phenotypic and genotypic characterization of Mycobacterium africanum isolates from West Africa. J Clin Microbiol 37:1921-1926.

Hall TA (1999) BioEdit: a user-friendly biological sequence alignment editor and analysis program for Windows 95/98/NT. Nucl Acids Symp Ser 41:95-98.

Huard RC, Lazzarini LC, Butler WR, van Soolingen D Ho JL (2003) PCR-based method to differentiate the subspecies of the Mycobacterium tuberculosis complex on the basis of genomic deletions. J Clin Microbiol 41:1637-1650.

Isea-Peña MC, Brezmes-Valdivieso MF, González-Velasco MC, Lezcano-Carrera MA, López-Urrutia-Lorente L, MartínCasabona N, Monforte-Cirac ML, Palacios JJ, PenedoPallares A, Ramirez-Rosales A, Sánchez-Silos R, TórtolaFernández T, Viñuelas-Bayón J, Vitoria-Agreda A (2012) Red de Laboratorios de Microbiología Servicio de Salud del Principado de Asturias (SESPA), Esteban J. Mycobacterium africanum, an emerging disease in high-income countries? Int J Tuberc Lung Dis 16:1400-1404.

Job JRPP (1998) Comparação de dados epidemiológicos da tuberculose pulmonar em Sorocaba, SP, Brasil, em uma década (1986-1996). Rev Saúde Pública 32:596-597.

Kent PT, Kubica GP (1985) Public Health Mycobacteriology: A Guide for the Level III Laboratory. Centers for Disease Control and Prevention, Atlanta.

Kraemer HC (1992) Evaluating Medical Tests. Newbury Park, Sage.

Kumar P, Nath K, Rath B, Sen MK, Vishalakshi P, Chauhan DS, Katoch VM, Singh S, Tyagi S, Sreenivas V, Prasad HK (2009) Visual format for detection of Mycobacterium tuberculosis and M. bovis in clinical samples using molecular beacons. J Mol Diagn 11:430-438.

Lee HR, Kim SY, Chang HE, Song SH, Lee HS, Park KU, Song J, Kim EC (2010) Novel multiplex PCR using dual-priming oligonucleotides for detection and discrimination of the Mycobacterium tuberculosis complex and M. bovis BCG. J Clin Microbiol 48:4612-4614.

Narayanan S (2004) Molecular epidemiology of tuberculosis. Indian J Med Res 120:233-247.

Raso A, Mascelli S, Nozza P, Ugolotti E, Vanni I, Capra V, Biassoni R (2011) Troubleshooting fine-tuning procedures for qPCR system design. J Clin Lab Anal 25:389-394.

Reddington K, O'Grady J, Dorai-Raj S, Niemann S, van Soolingen D, Barry T (2011) A novel multiplex real-time PCR for the identification of mycobacteria associated with zoonotic tuberculosis. PLoS One 6:e23481.

Rossau R, Traore H, De Beenhouwer H, Mijs W, Jannes G, De Rijk P, Portaels F (1997) Evaluation of the INNO-LiPA Rif. TB assay, a reverse hybridization assay for the simultaneous detection of Mycobacterium tuberculosis complex and its 
resistanceto rifampin. Antimicrob Agents Chemother 41:2093-2098.

Rothschild BM, Martin LD, Lev G, Bercovier H, Bar-Gal GK, Greenblatt C, Donoghue H, Spigelman M, Brittain D (2001) Mycobacterium tuberculosis complex DNA from an extinct bison dated 17,000 years before the present. Clin Infect Dis 33:305-311.

Ruggiero AP, Ikuno AA, Ferreira VCA, Roxo E (2007) Tuberculose bovina: alternativas para o diagnóstico. Arq Inst Biol 74:55-65.

Sales ML, Fonseca AA Jr, Orzil L, Alencar AP, Hodon MA, Issa MA, Soares Filho PM, Silva MR, Lage AP, Heinemann MB (2014a) Validation of two real-time PCRs targeting the PE-PGRS 20 gene and the region of difference 4 for the characterization of Mycobacterium bovis isolates. Genet Mol Res. 13:4607-4616.

Sales ML, Fonseca AA Jr, Sales EB, Cottorello AC, Issa MA, Hodon MA, Soares Filho PM, Ramalho AK, Silva MR, Lage AP, Heinemann MB (2014b) Evaluation of molecular markers for the diagnosis of Mycobacterium bovis. Folia Microbiol (Praha) 59:433-438.

Silva MR, Rocha AS, Costa RR, Alencar AP, Oliveira VM, Fonseca Jr. AA, Sales ML, Issa MA, Soares Filho PM, Pereira OTV, Santos EC, Mendes RS, Ferreira AMJ, Mota PMPC, Suffys PN, Guimarães MDC (2013) Tuberculosis patients co-infected with Mycobacterium bovis and Mycobacterium tuberculosis in an urban area in Brazil. Mem Inst Osw Cruz 108:321-327.

Sotiriadou I Pantchev N Gassmann D Karanis P (2013) Molecular identification of Giardia and Cryptosporidium from dogs and cats. Parasite 20:8.

Scorpio A, Zhang Y (1996) Mutations in pncA, a gene encoding pyrazinamidase/nicotinamidase, cause resistance to the antituberculous drug pyrazinamide in tubercle bacillus. Nat Med 2:635-636.

Telenti A, Marchesi F, Balz M, Bally F, Böttger EC, Bodmer T (1993) Rapid identification of mycobacteria to the species level by polymerase chain reaction and restriction enzyme analysis. J Clin Microbiol 31:175-178.

Teo JW, Cheng JW, Jureen R, Lin RT (2013) Clinical utility of RD1, RD9 and hsp65 based PCR assay for the identification of BCG in vaccinated children. BMC Res Notes 6:434.

Ueyama M, Chikamatsu K, Aono A, Murase Y, Kuse N, Morimoto K, Okumura M, Yoshiyama T, Ogata H, Yoshimori K, Kudoh S, Azuma A, Gemma A, Mitarai S (2014) Sub-speciation of Mycobacterium tuberculosis complex from tuberculosis patients in Japan. Tuberculosis (Edinb) 94:15-19.

Untergasser A, Nijveen H, Ra X, Bisseling T, Geurts R Leunissen JAM (2007) Primer3Plus, an enhanced web interface to Primer3. Nucleic Acids Res 35:W71-W74.

van Embden JDA, Crawford JT, Dale JW, Eisenach KD, Gicquel B, Hermans P, Martin C, McAdam R, Shinnick TM (1993) Strain identification of Mycobacterium tuberculosis by DNA fingerprinting: recommendation for a standardized methodology. J Clin Microbiol 31:406-409.

van Soolingen D, Hoogenboezem T, de Haas PE, Hermans PW, Koedam MA, Teppema KS, Brennan PJ, Besra GS, Portaels F, Top J, Schouls LM, van Embden JD (1997) A novel pathogenic taxon of the Mycobacterium tuberculosis complex, Canetti: characterization of an exceptional isolate from Africa. Int J Syst Bacteriol 47:1236-1245.

WHO (2013) Global Tuberculosis Report 2013. World Health Organization Library Cataloguing-in-Publication Data, Geneva, 306 pp.

All the content of the journal, except where otherwise noted, is licensed under a Creative Commons License CC BY-NC. 